AWEJ for Translation \& Literary Studies, Volume 5, Number4. October 2021 DOI: http://dx.doi.org/10.24093/awejtls/vol5no4.14

Pp. 180-189

\title{
The Poetics of Female Resistance in Eugene O'Neill's Long Day's Journey into Night
}

\author{
Olfa Gandouz Ayeb \\ English Department \\ The College of Humanities and Sciences Al Kharej \\ The University of Sattam Ibnu Abdelaziz \\ Saudi Arabia \\ Email: o.gandouz@psau.edu.sa
}

Received: 9/17/2021

Accepted: 10/13/2021

Published: 10/230/2021

\begin{abstract}
:
The present paper is an attempt to study the female quest for freedom in Eugene O'Neill's Long Day's Journey into Night from a French feminist perspective. Indeed, Mary Tyrone resorts to body language as a form of resistance against gender and cultural confinement. French feminism will be deployed to understand female non-verbal subversive strategies. Luce Irigaray argues that language is maledominated and male discourse misrepresents women. Accordingly, body language can be interpreted as a silent form of female resistance against patriarchal hegemony. It is the case of Mary who is irritated because of the male gaze and she uses madness as a silent language of resistance against female and ethnic stereotypes. Mary is a rebellious woman who defies her three men for being indifferent about her dilemma of disillusionment with the institution of marriage. She is treated as a wife, a mother or a daughter and she is often assigned the role of 'the Angel in the House.' French feminism will be used to understand the way O'Neill reshapes female identity and he calls for not linking female identity to the social roles. The aim is to study the non- verbal communication, the behavioural, kinetic, gestural and psychological profile of Mary. The paper will also focus on the hardships Mary faces and the ways she reconstructs female identity. The paper draws on the French feminist arguments about female madness as a form of resistance and it criticizes the conventional claim about madness as $\mathrm{s}$ form of weakness.
\end{abstract}

Key Words: French feminism, identity, gaze, non-verbal dialogue, symbolic order

Cite as: Olfa Gandouz, O. A. (2021). The Poetics of Female Resistance in Eugene O'Neill's Long Day's Journey into Night. Arab World English Journal for Translation \& Literary Studies 5 (4) 162-171.

DOI: http://dx.doi.org/10.24093/awejtls/vol5no4.14

Arab World English Journal for Translation \& Literary Studies 


\section{Literature Review:}

Eugene O'Neill's Long Day's Journey into Night has received a remarkable critical reception for its intriguing thematic concerns and its modern innovative style. Mary Tyrone, in particular has raised the interest of many critics who offer different interpretations and try to decipher Mary's enigmatic aspect. In this respect, Bloom embraces a psychoanalytic perspective and affirms that "O'Neill explores many dynamics that have been analyzed by Freud and his clinical disciples in the last century" (p.160). He argues that Mary is the object of male desire as her sons have an oedipal tendency and they seek for recapturing the motherly love. I will discuss this idea by showing that Mary resorts to body language as a form of resistance against the objectification of the female body. In addition to psychoanalysis, Edward Shaughnessy (1998) is another critic who has rather focused on the ethnic roots of Mary and he declares that Mary's tragedy springs from being disassociated from mother Ireland and from going through a dramatic experience of denigration. Shaughnessy explains: "the tragedy of Mary Tyrone, who stands for O'Neill's mother, can also be traced to childhood experience....Overly protected by her indulgent Irish father, Mary was much praised in convent school for her unworldliness" (p.157). The theme of ethnicity will be linked to female body language by showing that there is a split between body and soul. Mary is physically dwelling in an American house and she is spiritually linked to her Irish home.

On the other hand, Hlmberg and Solorzano accentuate the tragic aspect of Mary and they agree that "O'Neill transmutes melodrama into tragedy. Mary Tyrone, the mother, dominates the play, and the circumstances of her life illustrate how O'Neill forces the stuff to melodrama to yield tragic insight" (p.425). In other words, the tragedy of Mary lies in being entrapped in a vicious circle of self-estrangement. The present paper will deepen the idea of female tragedy by focusing on Mary's attempt to go beyond her tragic reality, her endeavor at removing the social fetters and her use of body language as a subversive tool against gender discrimination.

\section{A French Feminist Interpretation of Body Language:}

From a French feminist perspective, women are not able to express themselves explicitly and they do not have a voice of their own because language is male- dominated. In this respect, Irigaray challenges the Lacanian male symbolic order "given that [it] lacks a grammar that could articulate the pre-oedipal mother daughter relationship" (Barker, 2014, p.57). Luce Irigaray argues that the symbolic order multiplies the otherness of the female self and it misrepresents women. She denounces the Lacanian separation between language and body and underlines the affinities "between language and the sexed body, and between the economy of material exchange and the economy of discourse" (Martin, 2000, p.75). She is clearly criticizing the Lacanian interpretation of the symbolic order since it serves the patriarchal hegemonic agenda. In "the wedding between body and language," Irigaray notices that "sensations are divided according to dichotomous logic: pleasurel pain, activel passive, masculine, feminine, along with other dichotomies" (Irigaray, 2001, p. 23). She criticizes the split between the female body and language and calls for a better representation of women by "constituting an incarnate relationship which is realized by flesh and words" (Irigaray, 2001, p.28). In other words, Irigaray condemns female misrepresentation by the patriarchal symbolic order and calls for a better representation of women. She is among the feminists who call for the discovery of "a language which accompanies that bodily experience, 
clothing it in words that do not erase the body but speak the body" (Irigaray,1993, p.13). Speaking the female body is a reaction against its commodification and against its consideration as a passive vessel for male desire.

In her chapter "the wedding between the body and language," Irigaray rejects the objectification of the female body and she is opposed to the "exile of the body from its organization in a whole and its incarnation via language, a language which remains, for this reason, distinguished by listening and fecundity (Irigaray, 2001, p.23). The situation of passivity, the fact of being silenced and of being prevented from having access to a language which represents her encourage Long Day's Journey Mary to go beyond the linguistic barriers by relying on body language. Mary spends the play unearthing the memories of the glorious past and she often avoids eye contact. She is isolated and she is often lost in thoughts about the past because of the dreary reality of family dysfunctionality. She invents her own world when she avoids talking to her three men and she prefers to be confined in the spare room where she gives reins to the sweet past to dominate her mental roadmap. She uses the language of the eyes, gestures, monologues and madness as a non-verbal language of female resistance. The next part will deal with a textual analysis of female body language and it will give textual evidence about the non-verbal tools of resistance. This language is meant to be a mode of expression which would endow Mary with the chance of exteriorizing her repressed feelings and her censored thoughts. In this way, body language can be considered as compensation for female social repression.

\section{The Language of the Eyes:}

Female body language can be detected through the examination of stage directions. Brecht asserts that the function of the stage directions is to make the protagonists "connect with the audience not only verbally but through the use of body language" (Elsden, 2016, p.28). The bodily description of Mary is introduced in the opening stage directions:

Thin and pale with the bone structure prominent ..her forehead is framed by thick pure white hair...her hands are never still...her hands are never still. They were once beautiful hands...but rheumatism has knotted the joints and warped the fingers, so that now they have an ugly crippled look. (p.12)

This detailed physical portrayal gives an insight into Mary's life weariness. Her fatigue stems from her seclusion in a patriarchal and tight attic where she is left alone and denied access to family warmth. Her paleness, her hands and fingers show the effects of the passage of time on her body. "Her ugly crippled look" translates her embarrassment and her dissatisfaction with having an instable home. This language of the eye reflects Mary's retreat into loneliness and her yearning to return to her Irish home. In her moment of speculation, Mary "pauses looking out of the windowthen with an undercurrent of lonely yearning.) Still, the Chatfields and people like them stand for something. I mean they have decent, presentable homes they don't have to be ashamed of' (p. 38). Visual imagery entails Mary's envy for the Yankees as they succeed at constructing stable homes and functional families. The Irish woman blames her husband for his carelessness and for letting members of his family down. What is specific about Mary is that she avoids eye contact and she avoids the suspicious eyes of her sons. The evasive eyes indicate her uneasiness and her fear of 
being accused of constructing a dysfunctional family. She often confides to Edmund her irritation for having a reckless husband and she informs her son: "I know it's useless to talk. But sometimes I feel so lonely" (p. 39). The useless talk shows that language fails to help Mary reveal her inner turmoil and her deep longing for being settled down in a real home. When her husband asks her to forget about the remote past, "she (stares at him defiantly now): come to think of it I have to drive uptown. There's something I must get" (p. 74). The resistant stare implies Mary's use of the language of the eye as a form of subversion. She stares at her husband and then leaves the stage to drink her daily dose of morphine. She resorts to morphine in order to go beyond the tragic dilemma of being left behind by her husband who often displays a selfish behavior and prevents her from materializing the dream of family union. Unlike Mary who uses the language of the eyes as a form of expression, her son humiliates his father by using violent terms. He rebukes him for being irresponsible and for multiplying Mary's dilemma. He screams: "when I think of it I hate your guts! You've never given her anything that would help her want to stay off it! No home except this summer dump in a place she hates" (p. 122). Blaming the father shows that Edmund sympathizes with his mother; this sympathy proves Mary's success at exteriorizing her inner turmoil through her body language.

\section{The Doubleness of the Female Self:}

In addition to the language of the eyes, paralinguistic features can be examined through Mary's facial expression. In the last act the playwright reveals: "the uncanny thing is that her face now appears so youthful. Experience seems ironed out of it" (p.150). The presence of the uncanny confers a gothic atmosphere and announces the return of the alienated female self. The French Feminist, Helene Cixous argues that the uncanny "never completely disappears. Neither real, nor fictitious, a hybrid body composed of language and silence that invents doubleness and death" (as cited in Bellamy, 1992, p.181). Doubleness is traced through the discrepancy between dream vs. reality, illusion vs. truth, the present vs. the past, the young and the old Mary. The uncanny shows Mary's detachment from the house of the Tyrones and her backward journey into her Irish home where she used to be gifted with family amiability. Not only is the uncanny noticed through the facial expression of Mary, but is also displayed through her nostalgic attitude and her innocent behavior: "there is at times an uncanny gay, free youthfulness in her manner, as if in spirit she were released,...to become again the schoolgirl of her convent days" (p. 83). The uncanny manner suggests the split between body and soul and translates Mary's attempt to liberate herself from the social burden of being a mother and a wife. She moves from reality to the past when "[she stammers....Then, there is again a pause of dead silence. When she speaks again, her face has cleared and calm, and the quality of uncanny detachment is in her voice and manner). I am going upstairs for a moment if you'll excuse me" (p. 64). She rejoices while remembering the days of teenagerhood when she used to be a free girl who does not bear any responsibility. She goes beyond the patriarchal restrictions imposed on her when she decides to be disconnected and "imagines a world in which she would have a story separate from that written for her by her male kin" (Barlow, 1998, p. 175). She rebels against her husband who leaves her and who is preoccupied with his acting

career.

Mary's uncensored words are better heard in her soliloquies where she removes all the masks and becomes more spontaneous. In one of her soliloquies "(She stares about the room with 
frightened, forsaken eyes and whispers to herself): You're lying to yourself again. You wanted to get rid of them....You're gled they 're gone" (p. 82). The strange stares indicate the estrangement of Mary and evoke the wide gap between the mother and the three men. Mary's ambivalent attitude of blaming James for his indifference and her personal choice of being indifferent to the needs of her three men is the outcome of her psychological anxiety. In fact, Mary cannot forget the fact of being left alone by her husband and she accuses him of bringing about her spiritual death: "The wedding gown was the death of me" (p. 99), she laments. The spiritual death is another example of the split between body and soul; Mary is physically present in the house of the Tyrones, but she is absent minded as she keeps going back to the past and lamenting the loss of family bonds. She wants to get rid of her three men to have a larger space for meditation and for recalling the ghost of the past. However, her meditation is stopped by the voice of the foghorn which removes Mary back into her doleful reality of being imprisoned in a strange space: "it's the foghorn I hate. It won't let you alone. It keeps reminding you, and calling you back....It's just an ugly sound" (p. 85). The auditory imagery implies the use of sensory language which reverberates Mary's exasperation and her consideration of existence in a house devoid of endearment as a curse.

Accordingly, she leaves her husband, escapes reality and creates her own world, especially when she admires the foggy atmosphere. In this respect, she confesses that she appreciates the presence of fog because "it hides you from the world and the world from you.... No one can find you or touch you any more" (p.84). The fog is thus a refuge from the dismal reality of the failure to reconstruct a functional family. In this context, the critic Anne Flesche (1997) notices that "the close affinity between transformation and the denial of change is suggested through Mary's associations with morphine and fog" (p. 36). The fog is a symbol of denial as it contributes to blur the boundaries between reality and illusion and it helps Mary have a selected memory. Indeed, in the fog Mary "hides and loses herself" (p. 120); she is lost in the memories of the golden past when she used to experience moments of joy. "Only the past when you were happy is real" (p. 84), she affirms. Mary's spiritual journey back to the past provides her with security because it reminds her of the Irish sweet home where she used to be a slender girl. The chasm between the past and the present heightens the dramatic cadence which is manifested through Mary's seclusion and it will be followed by her madness. One of the dramatic moments is noticed when Mary is totally disconnected from the world of the Tyrones: "the strange detachment in her manner has intensified. She has hidden deeper within herself' (p. 82). The physical and spiritual detachment are incurred by Mary's disillusionment with the American dream of having a happy family. She has experienced a traumatic experience after crossing the Atlantic Ocean and being the victim of an unhappy marriage. In this respect, she pokes fun at her husband: "the really good servants are all with people who have homes and not merely summer places" (p. 53). Her voice is marked by the use of a tragicomic tone; the comedy lies in having a servant for the summer home and the tragedy can be recognized through Mary's feelings of homelessness and of being ignored by her husband. She is dissatisfied with having a summer house which multiplies her feelings of estrangement instead of endowing her with a sense of comfort. She also overblames her husband for being engrossed in achieving affluence and she regrets leaving the mother land and accompanying a husband who focuses on his talent as an actor and does not encourage his wife who used to be fond of playing piano. 
Mary is irritated because of her old age and she becomes alienated even from her own body. This type of alienation is noticed when Mary is embarrassed at the sight of her fingers. She reveals: "I couldn't play [piano] with such crippled fingers, even if I wanted to....I won't look at them. They're worse than the foghorn for reminding me" (p. 89). Her fingers remind her of her dysfunctionality and show the effects of the passage of time on her body. The damaged fingers also add to the dramatic intensity as they remind Mary of the split between the past when she used to be actively interested in developing her artistic skills and the present when she is imprisoned in the house of the Tyrones and does not have the chance even to hang around with her family members. Thus, different selves are lurking behind Mary's consciousness. In fact, "the real self has crippled through her fingers and been replaced by a goulish double, she like everyone else in this play, retreats from consciousness into the fog' (Holmberg and Solorzano, 2014, p. 425). The retreat proves the estrangement of the female self which is ashamed of facing the real reality of oppression, solitude and failure. This doubleness of the female self is a language of escape and a sign of Mary's dissatisfaction with the bodily transformation into an older woman. The transformation of the body affects Mary's psychological side as she keeps longing for remaining a virgin.

\section{Female Madness: A Silent form of Resistance}

The best form of body language in the play is made manifest through Mary's madness. From a French feminist perspective, Cixous argues: "the madwoman is a heroine, a powerful figure who rebels against the family and the social order; and the hysteric [...] refuses to speak the language of the patriarchal order" (as Cited in Showalter, 1993, p. 9). Put differently, female madness is a silent transgressive language of resistance. While men resort to language as a means of expression, women use body language as a way to exteriorize their repressed feelings and to react against social confinement. From a French Feminist view, women resort to madness because "they cannot do anything but mimic a language they have not produced" (Oliver, 2000, p. 224). Mimicry is based on imitating male discourse and subverting it at the end of the play. It is the case of Mary who rebels against her three men in the scene of madness by avoiding them and by being indulged in a nostalgic moment.

In her final meeting with the audience, Mary is reminiscent of Lady Macbeth during the sleepwalking scene and in her hysterical moments. Lady Macbeth's madness is perceived by the doctor of the play as the expiation of evil acts. "This disease is beyond my practice" (p. 55), declares the doctor in Macbeth. He is obviously not able to interpret female madness using scientific terms and he concludes that Lady Macbeth's madness is the outcome of malice. Unlike the Elizabethan lady whose madness announces her tragic end, Mary's madness is a sign of her liberation from the patriarchal manacles. Mary is agitated, she avoids using a male language which misrepresents her and she uses her body as a form of expression. One of her three men is embarrassed and he reveals his inability to decode the movement of Mary on stage. He complains about her mystery using the following terms: "she moves above and beyond us, a ghost haunting the past, and here we sit pretending to forget, but straining our ears listening for the slightest sound" (p. 133). The use of the prepositions "above" and "beyond" translates Mary's movement beyond the patriarchal norms. What is specific about Mary is that she goes beyond the temporal and spatial limits, makes the past a reality and succeeds at overturning the traditional gender roles. This 
reversal occurs when she gives her wedding dress back to Tyrone and leaves her three men "frozen in silence: Tyrone stirs in his chair. Edmund and Jamie remain motionless" (p.156). Mary silences the three men after being silenced for a long moment; giving the wedding dress epitomizes the movement from experience to innocence and the refusal of the social roles ascribed to her. She leaves the stage and keeps looking for a stable home. This desire translates her lamentation over the failure to establish a functional family. The inability to achieve inner peace pushes Mary to freeze the glorious moments of the past when she was endowed with the chance of being "so happy for a time" (O'Neill, 1984, p. 156). The use of the word happy creates a sort of black humor and an atmosphere of absurdity. Actually, Mary is an unhappy lady who keeps escaping the present and is tragically looking for "something [she] needs[s] terribly. [She] remember[s]when [she] had it [she] was never lonely nor afraid" ( $\mathrm{p} .153)$. She is obviously longing for the Irish family warmth and is nostalgic to the days of childhood when she used to be surrounded by family protection.

\section{Body Language: From Page to Stage}

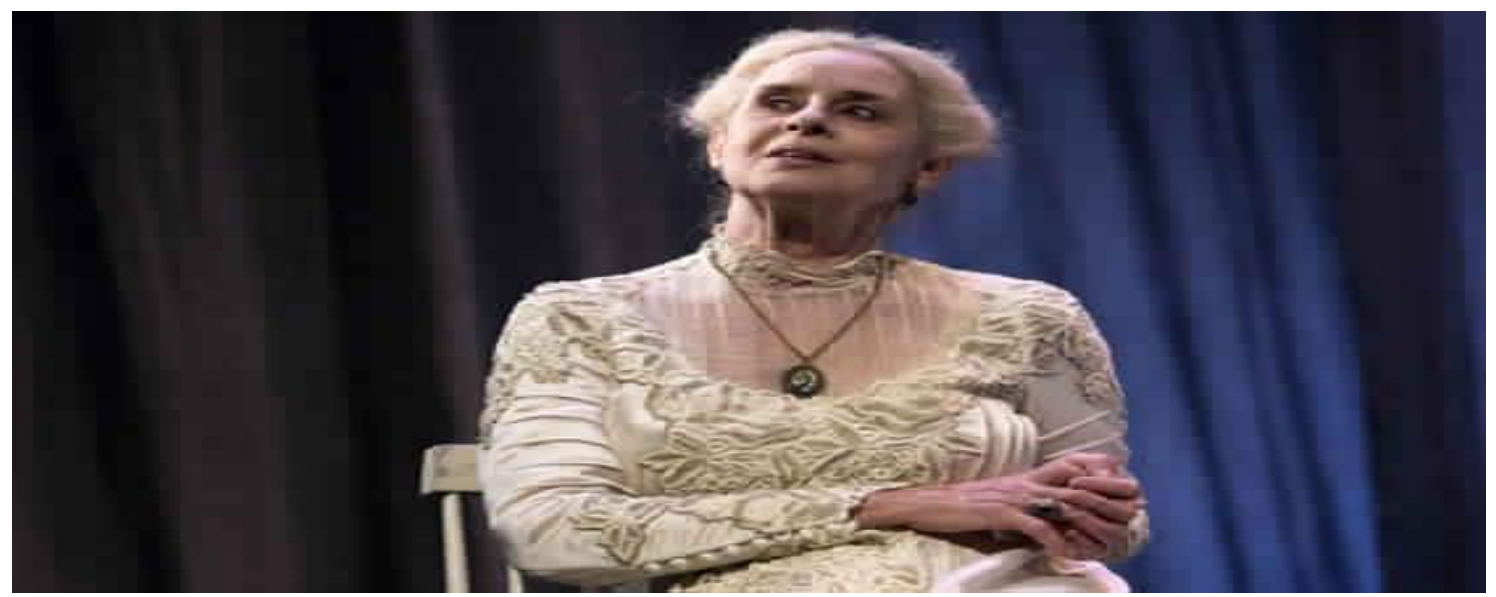

Figure 1. Storrio, R. (2015). Vicky Pena. [Online image]. https://www.diariosur.es/culturas/201501/21/vicky-pena-muchos-anos20150120232520.html

Mary's body language can be better understood through the movement from page to stage and through the performance of some talented actresses. The picture above is part of the 2014 production in which Péna's Mary is moving from the present to the past (Storrio, 2015). Accordingly, her face becomes radiant and she has a confident glare of security. She forgets about the crippled fingers because she is indulged in the sweet memories of girlhood. The Spanish production of 2014 (under the direction of Juan José Afonso) is one of the most successful productions as actress Vicky Péna intended to highlight the oversensitivity of Mary and her dilemma through zooming her body language. In this respect, the theatre researcher Schodel (2014) observes: "remarkable in her dramatic talents, she enhances the text with her facial expressions, intonation and gestures, delivering a powerful and highly emotional performance" (p. 245). The actress is inspired by the stage directions which portray Mary's physical movement on stage. For instance, when the Tyrones are grouped together for lunch, Mary does not feel at ease "her expression shows more of that strange aloofness which seems to stand apart from her nerves and

Arab World English Journal for Translation \& Literary Studies 
the anxieties which harry them" (p. 61). Her anxiety stems from the male gaze and it reflects the desire to avoid the suspicious eyes of her three men. Péna adds a dramatic touch to Mary's silent language as she puts extra emphasis on the emotional aspect. The audience experiences a cathartic moment and identifies with Mary, especially when she uses a pathetic tone: "[her lips quivering pitifully]: I can't bear having you remind me" (p. 49). She feels frustrated as Edmund reminds her that she shares the responsibility of having a dysfunctional family. Her lips reveal her deep rejection of being offended and dramatizes her situation of disintegration within her summer home. Péna plays on the sensitivity of Mary and sheds light on her female plight by working on the visual side. For example, there is a sudden shift from having a pale face and eyes in the morning to having a bright face and glamorous eyes at night. In fact, "Péna's Mary is pure emotion.... She becomes a ghostly person at night as she retreats to her childhood memories" (p .244). The theatrical focus on body language, facial expressions and the language of the eyes is meant to probe into Mary' inner workings and to grasp her non-verbal communication.

The significance of this paper resides in deciphering the non-verbal communication of Mary Tyrone and in showing O'Neill's voice of resistance against female dependence. The paper is limited in the sense that it does not delve into the intricacies of the female self in a detailed way, but it succeeds at translating Mary's body language as a prolific tool of resistance against the patriarchal hegemony. The open ended structure of the play invites the audience to have new speculations about female freedom and the decision to quit the male centered world of the Tyrones suggests Mary's success at creating a world of her own. The merit of Mary Tyrone lies in her triumph at the reversal of the patriarchal mold and at her act of disobedience. She leaves the stage after making her male relatives aware of their tragic mistakes and after making them assume the responsibility of their indifference. In this respect, Tyrone recognizes his mistake of leaving Mary alone at times of urgent needs and he regrets the fact of giving priority to materialism over emotions. He is conscious that Mary's madness stems from the patriarchal confinement, domesticity, ethnic disintegration and family gaps. However, Mary can be blamed for escaping into the past and for moving from the house of the Tyrones to the house of girlhood where her father used to be another Irish patriarch. She can be blamed for her unrealistic choices and for being responsible for her isolation, but the paper has been an attempt to provide Mary with a mode of expression and to reveal her inner dilemma. The aim is to raise the audience's awareness about the role of body language in reflecting female plight. Body language has proved to be a form of female resistance and another language against muffled female voices. Studying the way male playwrights defend female rights is an interesting topic which counters the claims about the misogynist attitude of some modern and postmodern playwrights. Studying female body language as a form of resistance delivers a message about dismantling the barriers of patriarchy and of misrepresenting women.

\section{Conclusion:}

Analyzing Mary's body language from a French feminist angle helps us conclude that Mary "[uses] her body as voice. Manifesting physically the restrictions imposed on her" (Vasello, 2007, p. 35). She reconstructs female identity when she refuses to play the role assigned to her by her husband and when she creates her own world when she resorts to the past as a reality. In this way, she copes with the law of the father and she prefers to be immersed in fantasy instead of facing the bitter reality of failure. The best form of coping with social obligations is witnessed during the 
mad scene which is a language of resistance against the loss of a stable home. Despite the fact that Mary is again imprisoned within the walls of the Tyrones home at the end of the play, she has partially succeeded at exteriorizing her inner malaise; body language has helped Mary release her repressed frustration against gender exploitation and ethnic denigration.

\begin{abstract}
About the Author:
Dr. Olfa Gandouz is currently an assistant professor at the College of Sciences and Humanities al Kharej, Saudi Arabia. She is a permanent assistant professor at the University of Monastir, Tunisia. She got her doctoral degree from the Faculty of Arts and Human Sciences of Sousse, Tunisia on the topic of 'Female Oscillation between Idealization and Debasement in Selected Plays of Eugene O'Neill and Tennessee Williams'. ORCID ID: https://orcid.org/0000-00017271-3227
\end{abstract}

\title{
Acknowledgement:
}

I am grateful to the English Department at the College of Humanities and Sciences Al Kharej, Saudi Arabia for encouraging scientific research. I am also grateful to the English Department at the University of Sousse, Tunisia where I learned the roots of academic research

\section{References}

Barker, C. (2004). The Sage Dictionary of Cultural Studies. London: Sage Publications. Barlow, J. “O’Neill's Female Characters.” Manheim, 164- 178.

Bellamy, J. (1992). Translations of Power. London: Cornell University Press.

Bloom, S. (2007). Student Companion to Eugene O'Neill. Connecticut: Greenwood Press. Eldsen, R., et al. (2016). Drama Study Guide. London: Rhinegold Education.

Fleche, A. (1997). Mimetic Disillusion. Tuscaloosa: The University of Alabama Press. Harris, A. (2000). Rewriting Difference from Woolf to Winterson. New York: University of New York Press.

Holemberg, A and Carlos Solorzano. (2014). The World Encyclopedia of Contemporary Theater. London: Routledge.

Irigaray, L. (1985). This Sex Which is not One. C. Porter. (Trans.). Ithaca: Cornell University Press.

Irigaray,L. (1993).“ Divine Women.” Sexes and Genealogies. Trans. G. Gill. (Trans.). New York: Columbia University Press, 57-72.

Irigaray,L. (2001). To Be Two. Routledge: New York.

Gilman, S. (1993). Hysteria Beyond Freud. Berkeley: University of California Press.

Manheim, M. (1998). The Cambridge Companion to Eugene O'Neill. New York: Cambridge University Press.

Martin, A. (2000). Luce Irigaray and the Question of the Divine. London: Maney Publishing. Oliver, K. (2000). French Feminism Reader. Oxford: Rowman and Littlefield Publishers. O’Neill, E. (1984). Long Day's Journey into Night. New Heaven: Yale University Press. Schodel, B. (2015). “Long Day's Journey into Night September 4, 2014.” Eugene O'Neill's Review 36.(2). Ireland: Pennsylvania State University Press.

Shakespeare, W. (2007). Macbeth. Ireland: Penguin Classics. 
AWEJ for Translation \& Literary Studies Volume, 5 Number 4. October 2021

Shaughnessey, E. “O’Neill's African and Irish Americans.” Manheim, 148-161. Showalter, E. "Hysteria, Feminism and Gender." S. Gilman. 286-345.

Storrio, R. (2015). Vicky Pena.[Online image].

https://www.diariosur.es/culturas/201501/21/vicky-pena-muchos-anos-20150120232520.html Vasallo, H. (2007). The Body Politics and the Illness Narrative. Oxford: Peter Lang. 